\title{
ANATOMIA FOLIAR E DO PEDÚNCULO FLORAL DE PLANTAS DE MORANGUEIRO (Fragaria $x$ ananassa) "gequoia" TRATADAs COM FITOREGULADORES
}

B. APPEZZATO-DA-GLORIA
S.H.G. MIRANDA-STALDER

RESUMO: O presente estudo teve por objetivo descrever a anatomia foliar e do pedúnculo floral do morangueiro "Sequóia" a fim de verificar os efeitos dos reguladores vegetais, ácido giberélico (GA3) e ácido naftalenoacético (NAA), e dos bioestimulantes Ergostim e Atonik, sobre as características anatômicas das plantas tratadas. A dose total empregada dos quatro produtos foi de $30 \mathrm{ppm}$, parcelada em três pulverizações, iniciadas após o infcio do florescimento. Foram analisadas amostras de folhas ( 1 imbo e peciolo) e o pedúnculo floral de 3 repetições. As análises histológicas foram feitas mediante o preparo e observação de lâminas de material fresco ou fixado. A analise da folha adulta revela a presença de hidatódios nas extremidades denteadas do limbo. A lamina foliar é anfiestomática, com estômatos do tipo anomocitico. Ocorrem dois tipos de tricomas: tectores e glandulares. Na epiderme abaxial podem estar presentes estruturas semelhantes à lenticelas. o mesofilo é dorsiventral. o padrão de venação é do tipo nervatio camptodroma arqueada típica. o peciolo apresenta estômatos e trico-

1 Departamento de Botanica da Escola Superior de Agricultura "Luiz de Queiroz" da Universidade de São Paulo, 13400 - Piracicaba-SP.

2 Acadêmica do Curso de Engenharia AgronômiCa/ESALQ/USP - 13.400-Piracicaba-SP. Bolsista FAPESP $(88 / 0845-0)$ 
mas cujas caracteristicas se assemelham ao do limbo; abaixo da epiderme ha um colênquima do tipo anelar; no parênquima fundamental há idioblastos contendo drusas e outros que contém compostos fenolicos; o cilindro vascular é descontínuo formando um arco, constituido de feixes do tipo colateral aberto envolvido por uma bainha parenquimatica amilifera. Os elementos traqueaís do xilema são espiralados. o pedúnculo floral apresenta epiderme com tricomas, colênquima do tipo anelar, um anel contínuo de fibras perivasculares e cilindro vascular descontinuo interrompido por raios medulares estreitos. Os produtos testados não alteraram a estrutura anatômica dos morangueiros "Sequóia", na dose empregada.

Termos para Indexação: morangueiro, fitorreguladores, anatomia foliar, anatomia do pedúnculo floral.

THE FOLIAR AND FLORAL STALK ANATOMY OF STRAWBERRY PLANTS (Fragaria $x$ ananassa)

"SEQUÓIA" TREATED WITH PLANT GROWTH REGULATORS

ABSTRACT: This paper describes the effects of the growth regulators, gibberellic acid (30 ppm), naphtalene acetic acid (30 ppm), the biostimulants Ergostim ( $30 \mathrm{ppm}$ ) and Atonik (30 ppm) on the anatomical features of foliar and floral stalk of strawberry (Fragaria $x$ ananassa) "Sequóia". Three weekly applications of $10 \mathrm{ppm}$ were studies. They started just after plants began blooming. The leaves (lamina and petiole) and the floral stalk harvested from three plants after the last pulverization. The histological studies were carried out by preparing and observing plant material slides. Observations of the plant slides allowed us to conclude that every leaf apex and marginal serration had a terminal hydathode region. The leaf blade was amphistomatic with anomocytics 
stomata. There were two types of trichomes: non-glandular and glandular. On the abaxial side, there were some structures similar to a lenticel. The mesophyll was dorsiventral. The venation pattern conformed to camptodromous type. The petiole had an uniseriate epidermis with stomata and trichomes, an annular collenchyma, some parenchyma cells with druses and the collateral bundles arranged in a descontinuous cylinder. The floral stalk anatomy different to the petiole because it had a continuous perivascular fibre ring and the vascular cylinder was almost continuous. The anatomy structure of the treated plants was not affected by growth regulators.

Index Terms: strawberry, growth regulators, biostimulants; foliar anatomy, flower stalk anatomy.

\section{INTRODUÇÃo}

- morangueiro cultivado (Fragaria $x$ ananassa Duch.) pertence a familia Rosaceae, sub-familia Rosoideae, da qual fazem parte, ainda, os gêneros Rosa, Potentilla e Rubus (CRONQUIST, 1981).

Segundo METCALFE \& CHALK (1950), as folhas das rosaceas são geralmente dorsiventrais. Os tricomas são comumente unicelulares, apresentando variaçőes estruturais; podem ocorrer tricomas glandulares, pedunculados e capitatos, por exemplo, em Fragaria. Alguns gêneros desta familia, inclusive Fragaria, possuem hidatódios nas folhas denteadas.

DONNELLY \& SKELTON (1987), analisaram a estrutura de hidatódios de morangueiros "Totem". De acordo com os autores, os "dentes" do limbo dos follolos apresentam um hidatodio na sua região terminal. Internamente, os hidatódios estão delimitados por uma bainha de feixes que acompanha os tecidos vasculares aproxi- 
mando-se da epiderme adaxial e delimitando a zona dos poros de água. Entre os traqueídeos terminais e os poros, há um tecido de células parenquimáticas, clorofiladas, arranjadas frouxamente, pequenas e com paredes delgadas, denominado epitema. Observaram, ainda, que as células epidérmicas do hidatódio são menores, mais cúbicas, comparadas às demais células ordinárias adjacentes. Segundo METCALFE \& CHALK (1950), em algumas rosáceas, a superfície abaxial é papilosa. As paredes internas das células epidérmicas são, em geral, mucilaginosas. Há espécies com hipoderme; e os estômatos, quase sempre, estão confinados à face abaxial.

No mesofilo da familia em estudo podem ocorrer duas ou mais camadas de células em paliçada (METCALFE \& CHALK, 1950). ESAU (1965), cita, entre outras espécies, Fragaria elatior, na qual a maior parte dos cloroplastos estāo contidos no parênquima paliçádico e não no lacunoso. A mesma autora relata que em folha de pêra (Pyrus malus) as células da bainha dos feixes também apresentam cloroplastos, porém em menor quantidade do que no mesofilo. Segundo METCALFE \& CHALK (1950), nesta família, os feixes vasculares das nervuras menores podem possuir, ou não, esclerênquima na bainha que os envolve.

De acordo com METCALFE \& CHALK (1950), o peciolo de Fragaria exibe, em secção transversal, uma estrutura de feixes vasculares em arco. Os cristais de oxalato de cálcio podem estar presentes. isolados ou em grupos.

ESAU (1984), observa que a ocorrência de lenticelas é mais comum na periderme de caules e ralzes. A autora cita que Malus e Pyrus, ambas rosáceas, possuem lenticelas.

METCALFE \& CHALK (1950), descrevem que no caule desta familia, a porção mais externa do córtex é, frequentemente, colenquimatosa nas espécies lenhosas e, às vezes, certos gêneros apresentam grupos de células pétreas ou 
fibras. No caule de certas espécies foram observadas células mucilaginosas no córtex primario, raios parenquimáticos e na medula. Segundo os autores há uma endoderme bem definida no caule do gênero Fragaria. o periciclo no caule de gêneros lenhosos é inicialmente provido com feixes de fibras, mas subsequentemente desenvolvem-se grupos de células pétreas entre eles e formam, em certas espécies, um anel descontinuo. Porém, em alguns representantes de Fragaria ocorre um anel esclerenquimático contínuo. Os feixes vasculares são bem separados por raios parenquimáticos sendo claramente visiveis como unidades distintas. A medula pode ser, ou não, homogênea; em tecidos parenquimáticos é comum a presença de idioblastos contendo tanino.

Há muitas evidências de que as giberelinas bem como as auxinas estão envolvidas no crescimento em extensão dos tecidos vegetais. - estímulo ao alongamento do caule é um dos exemplos de efeito do ácido giberélico (WAREING \& PHILLIPS, 1970). O efeito sobre a altura de planta, consequência do alongamento dos entrenós, um dos mais estudados do ácido giberélico, é descrito como resultado do incremento do comprimento ou do número de células ou de ambos (GUTTRIDGE \& THOMPSON, 1959).

o crescimento da planta de morangueiro é muito afetado por vários fatores ambientais. Dias longos aumentam o tamanho da planta, promovendo o alongamento de pecíolos, lamina, pedúnculo dos frutos e estolhos. O efeito das giberelinas em morangueiro é semelhante ao dos dias longos, incrementando o crescimento vegetativo. o comprimento dos pecíolos tem sido usado como medida do crescimento vegetativo desta planta (PATHAK \& SINGH, 1978).

Em 1959, GUTTRIDGE \& THOMPSON, trataram plantas de morangueiro com ácido giberélico. Nas folhas amostradas o número e o comprimento das células epidérmicas aumentaram. 
PATHAK \& SINGH (1978), analisaram os efeitos do GA (75 ppm) e do fotoperiodo sobre a anatomia de cultivares de morango. o produto aplicado estimulou o comprimento do peciolo, acompanhado do alongamento das células do parênquima e da epiderme; a largura das mesmas não foi afetada. Tanto o GA quanto o fotoperiodo longo provocaram um aumento do tamanho do feixe vascular central, número de fileiras de xilema e o número e tamanho dos vasos do xilema do feixe central do pecíolo. Na lâmina foliar as células epidérmicas das duas faces sofreram um alongamento, neste caso, a largura das mesmas também aumentou consideravelmente; os mesmos resultados obtidos nos feixes do pecíolo foram observados para o limbo. Além do alongamento das células do pecíolo houve incremento do seu número.

Sabe-se que as auxinas, dependendo de sua concentração, podem estimular ou inibir o crescimento da nervura central e feixes maiores, mas têm pouco efeito sobre os pequenos feixes que cortam o mesofilo. As auxinas parecem necessárias ao crescimento dos vasos condutores, atuam na divisão de células cambiais, dirigindo a formação dos tecidos vasculares do xilema e do floema (WAREING \& PHILLIPS, 1970). Segundo AUDUS (1964), as auxinas influenciam na diferenciação histológica dos pecíolos.

Segundo BRADLEY et alii (1968), os autores Pickett e Bates obtiveram aumento na espessura de parênquima paliçádico em folhas de macieira tratadas com ANA (ácido naftalenoacético).

o presente estudo teve por objetivo descrever a anatomia foliar e do pedúnculo floral do morangueiro "Sequóia" a fim de verificar os efeitos de reguladores vegetais nas caracteristicas anatômicas das plantas tratadas. 


\section{MATERIAL E MÉTODOS}

o experimento, no campo, foi iniciado com o transplante das mudas do morangueiro "Sequóia" para um canteiro do Setor de Horticultura da ESALQ/USP. Os reguladores vegetais usados foram o ácido giberélico (GA3), o ácido naftalenoacético e os bioestimulantes Ergostim e Atonik, todos na dose de $30 \mathrm{ppm}$, parcelada em três pulverizações, com intervalos semanais, a partir do surgimento da primeira influorescência. Uma semana após a terceira e última aplicação dos produtos foram coletados exemplares para proceder ao estudo anatômico das folhas e pedúnculos florais.

Para a análise das estruturas anatômicas, foram coletadas três plantas representativas de cada tratamento. o limbo foliar foi dividido em cinco regiões de estudo, apice, meio, base e margem e nervura secundária; o pecíolo e o pedúnculo floral foram amostrados na sua porção mediana. O material selecionado foi fixado em FAA 50, desidratado, emblocado em parafina, cortado e, em seguida, as fitas foram distendidas sobre as lâminas, conforme SASS (1951). A espessura dos cortes variou de 10 a 15 micrômetros. À desparafinação dos cortes com xilol, seguiu-se a sua coloração pela safranina e "fast-green" (SASS, 1951), e a montagem em lâminas com resina sintética.

Foram feitos cortes a mão livre para a comparação do material fresco com o fixado. A coloração usada foi a do verde iodo e vermetho congo (DOP \& GAUTIE, 1928).

Para os testes histoquímicos também foram feitos cortes a mão livre de material fresco. A natureza dos cristais de oxalato de cálcio foi comprovada pela aplicação de ácido sulfúrico nos cortes, com a formação de cristais aciculares de sulfato de cálcio (CHAMBERLAIN, 1938). A presença de tanino foi testada com sulfato ferroso e com cloreto 
férrico (JOHANSEN, 1940) e do amido, com lugol (BUCHERL, 1962) e com cloreto de $z$ inco iodado (STRASBURGER, 1913).

A lignina, celulose e suberina identificadas pelo emprego do cloreto de $\mathrm{z}$ inco iodado (STRASBURGER, 1913); substâncias graxas pelo SUDAN III e SUDAN IV (JOHANSEN, 1940); a cuticula pelo SUDAN IV (FOSTER, 1949).

o estudo da venação foliar foi efetuado em material herborizado, disfanizado em $\mathrm{NaOH}$ a 5\% e, posteriormente, em hipoclorito de sódio a 50\%, corado com safranina hidro-alcoólica e montado em resina sintética (FOSTER, 1949).

Para melhor observação do sistema vascular foi empregado o método de maceração de Jeffrey (JOHANSEN, 1940).

Os desenhos de anatomia foram executados ao microscópio óptico, com emprego de câmara clara e projeção de escala micrométrica paralelamente. Também foram tiradas fotomicrografias de material preparado em lâminas.

\section{RESULTADOS}

1. Descricão Anatômica do Morangueiro Sequóia

\subsection{Estrutura da Lâmina Foliar}

\section{Hidatódios}

Nas extremidades dos bordos denteados, a lamina foliar, em vista frontal, revela, na face superior, grande número de "estômatos" situados próximos uns dos outros, e, na face inferior, numerosos tricomas longos, unicelulares, acompanhando a margem.

Cortes transversais passando por esta região (Figura 1) mostram que, onde o mesofilo é modificado em epitema - tecido constiturdo por células parenquimaticas pequenas de paredes 
$\frac{5}{6}$
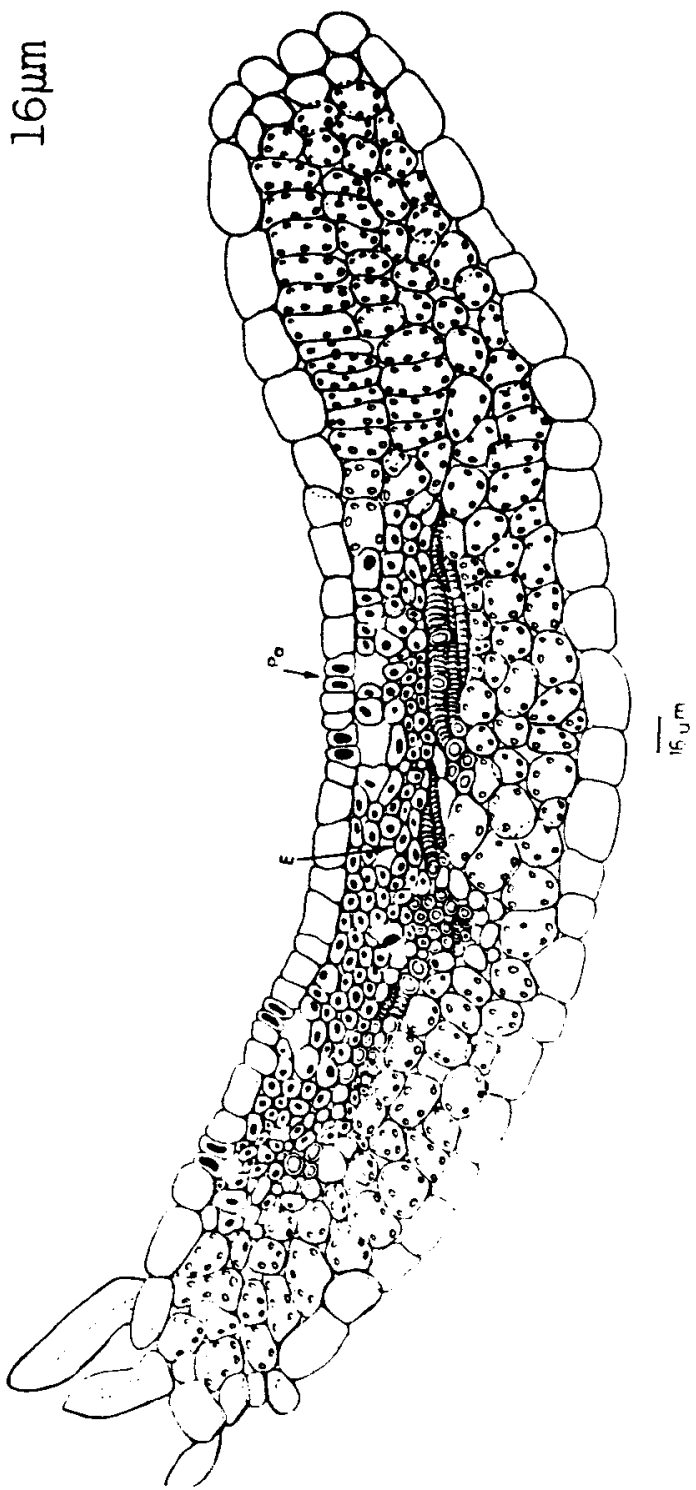

Figura 1 - Corte transversal do hidatódio. Nota-se o epitema (E, seta), os poros de agua ( $\mathrm{Pa}$, seta) e as terminaçōes vasculares. 
por células parenquimáticas pequenas de paredes finas, núcleo grande e desprovidas de cloroplastos, arranjadas frouxamente (Figura 1, E seta) - a epiderme apresenta estômatos modificados, os poros de água (Figura 1 - Pa seta). As terminações vasculares que chegam ao epitema são compostas de traqueideos espiralados (Figura 1).

\section{Epiderme}

É uniestratificada em ambas as faces da folha. Em vista frontal, nota-se que as células da epiderme superior são maiores que as da inferior (Figuras 2 e 3 ). A cutícula é mais espessa na face adaxial em relação à abaxial e mais espessa nos bordos que nas demais regiōes da folha (Figura 7 - seta). Os estômatos ocorrem em ambas as faces da folha, porém são mais numerosos na face abaxial (Figuras 2 e 3 ). As células-guarda situam-se num nível inferior em relação às demais células da epiderme e não apresentam nenhuma relação com estas, sendo classificadas, segundo METCALFE \& CHALK (1950), como estômatos anomocíticos (Figuras 2 e 3 ). ocorrem tricomas tectores e glandulares. Os primeiros são unicelulares, com paredes espessas, longos e aparecem, preferencialmente, na face abaxial, acompanhando as nervuras (Figura 4) . Os últimos, são unicelulares, unisseriados, pedunculados e capitados, parecendo em ambas as faces (Figura 3). Algumas células da epiderme reagem positivamente nos testes para compostos fenólicos.

Lenticelas

A análise da folha herborizada, ao microscópio estereoscópio revela a ocorrência na face abaxial, de pequenas protuberâncias de coloração marron, que aparecem sobre as nervuras e, algumas vezes, na lâmina. Estas sāo mais 


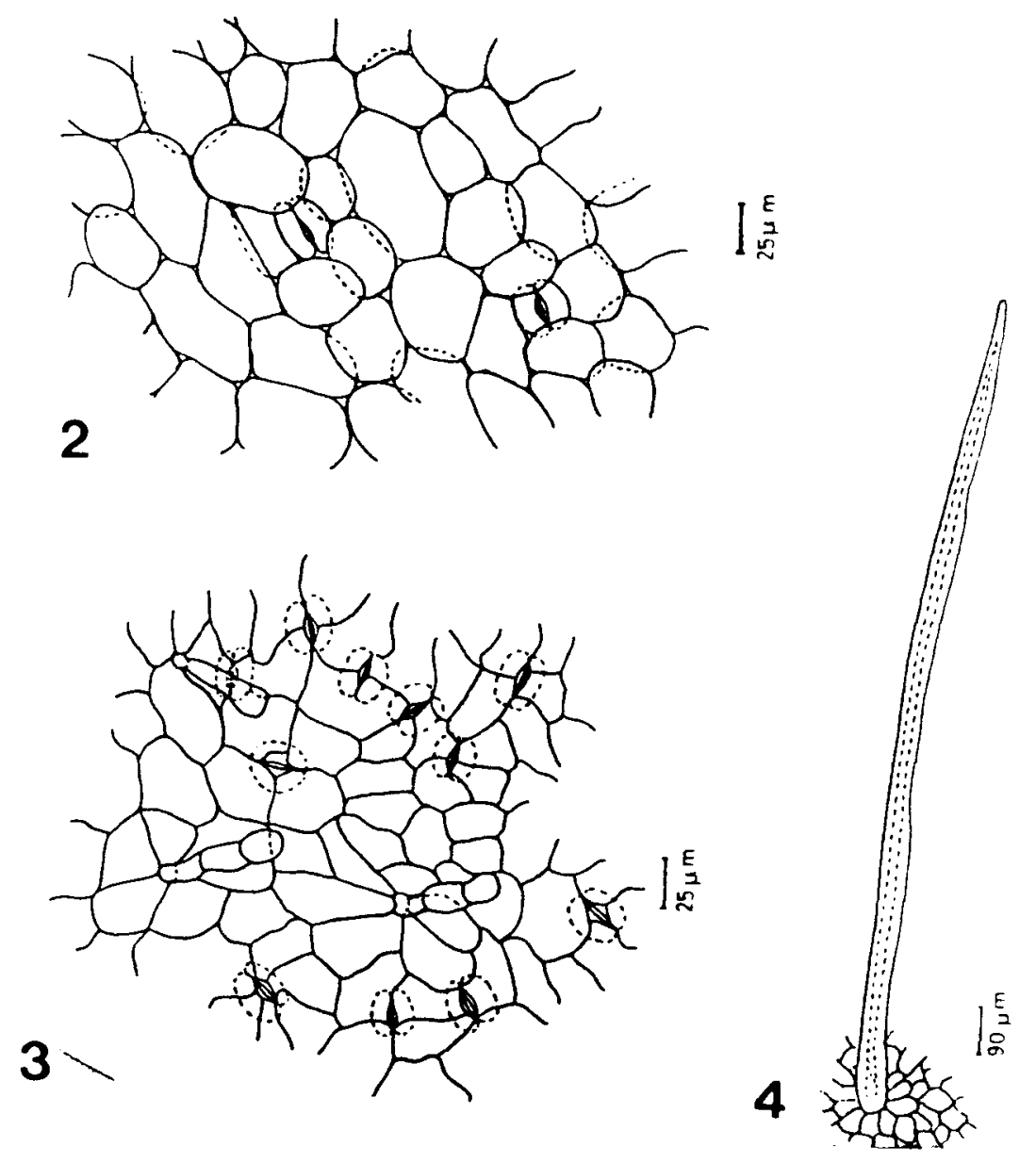

Figuras 2 e 3 - Vista frontal da epiderme das faces adaxial e abaxial, respectivamente. Na Figura 3, pode-se observar alguns tricomas glandulares.

Figura 4 - Vista frontal da epiderme abaxial mostrando um tricoma tector. 
frequentes junto aos bordos denteados da folha. os cortes transversais, passando por tais estruturais (Figura 5, seta) revelam que a elevação é decorrente da atividade de um felogênio que produz um tecido complementar compacto, com algumas células suberizadas que pressionam a epiderme em direção ao exterior, provocando seu rompimento.

\section{Mesofilo}

O mesofilo é dorsiventral (Figura 6). - parênquima paliçádico é representado por células longas, providas de numerosos cloroplastos e dispostas em duas a três camadas, sendo interrompido apenas ao nivel das nervuras, mantendo-se nos bordos (Figura 7). 0 parênquima lacunoso apresenta células de formas variadas, providas de cloroplastos e que estão dispostas em cerca de três camadas; algumas destas células são coletoras (Figura 8).

\section{Sistema Vascular}

Venação foliar - Esta espécie possui uma única nervura primária. As nervuras secundárias são conspicuas, surgem distantes umas das outras, correm para a margem, em arcos, sem a atingir e sem formar laços para a frente. Estas nervuras não convergem no ápice. De acordo com a classificação de ETTINGHAUSEN (1861), este padrão de nervação se enquadra no tipo nervatio camptodroma arqueada típica (Figura 9)

o corte transversal da região basal da folha (d) mostra a nervura central constituida por um feixe vascular colateral maior e, lateralmente, por dois feixes vasculares menores. Na região mediana (c) verifica-se ainda um feixe vascular maior e um feixe lateral menor. Como na base, os feixes vasculares ficam imersos num parênquima desprovido de cloroplastos, sendo envoltos por uma bainha constituida de 
ANAIS ESALQ, Piracicaba-SP. 48:127-154, 1991.

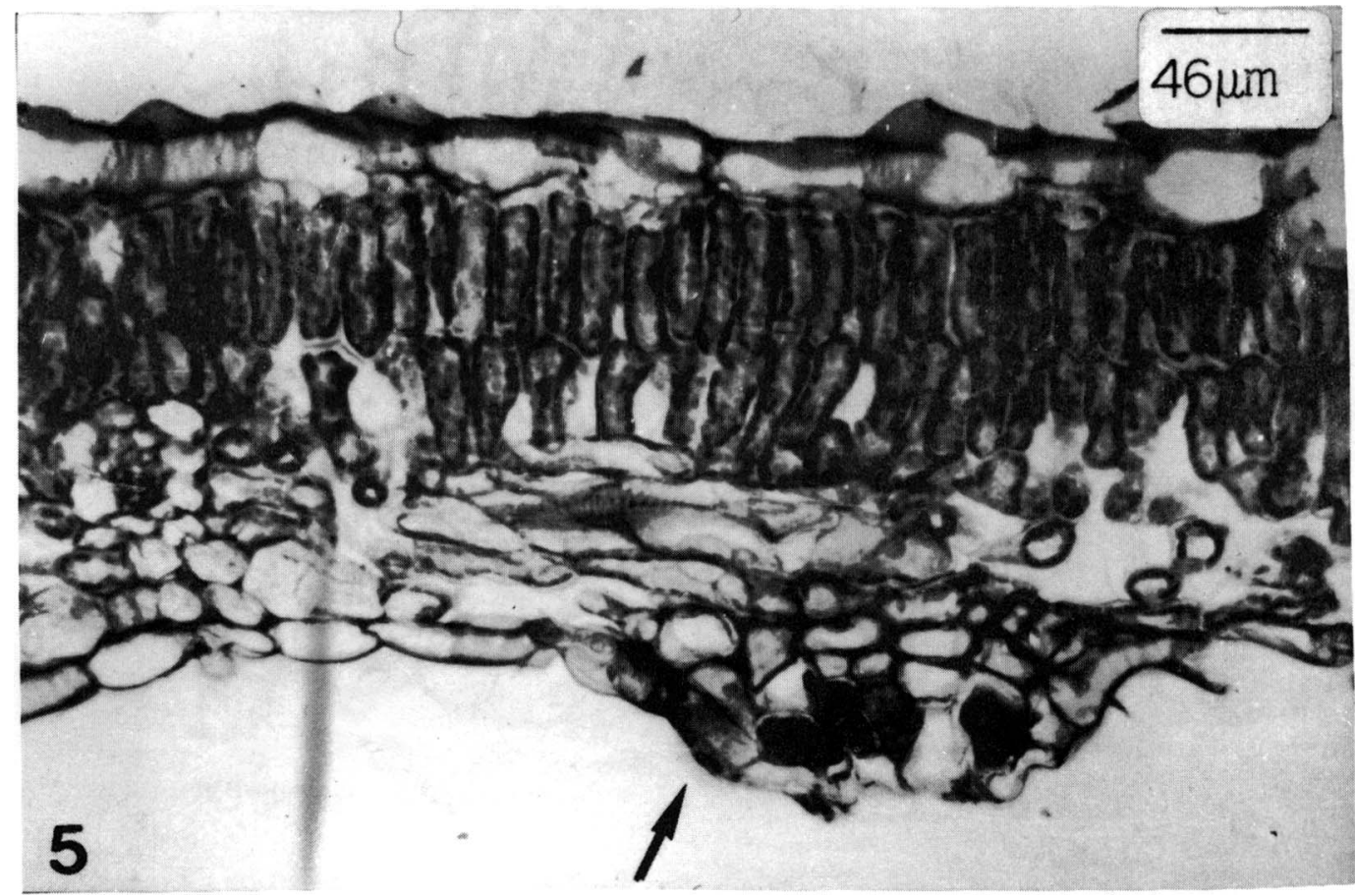
Figura 5 - Corte transversal do limbo foliar
passando por uma protuberância semelhante à uma lenticela (seta). 


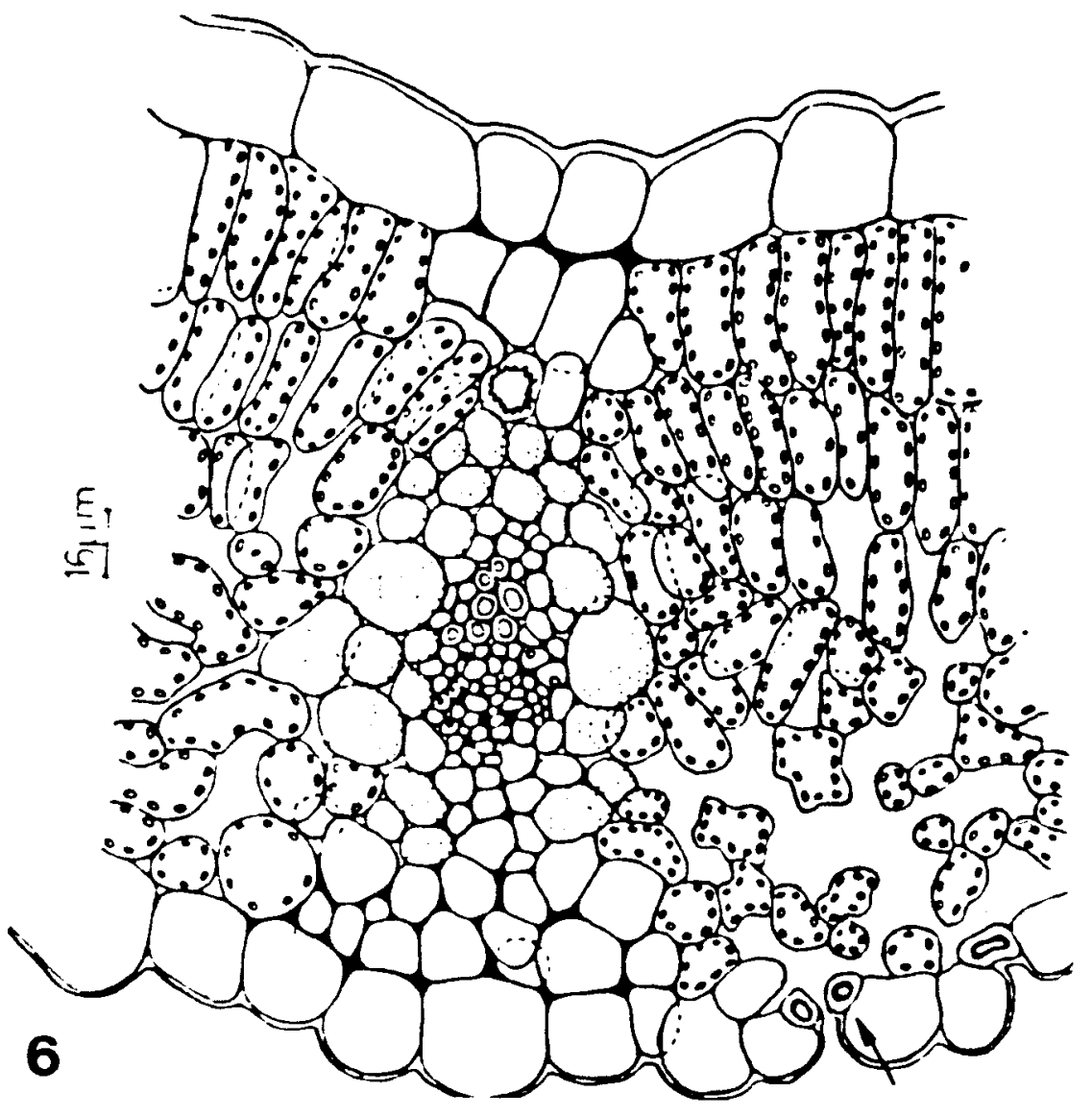

Figura 6 - Corte transversal do limbo foliar passando por uma nervura secundária. Observa-se o feixe colateral envolvido por uma bainha que se estende até as duas epidermes. 

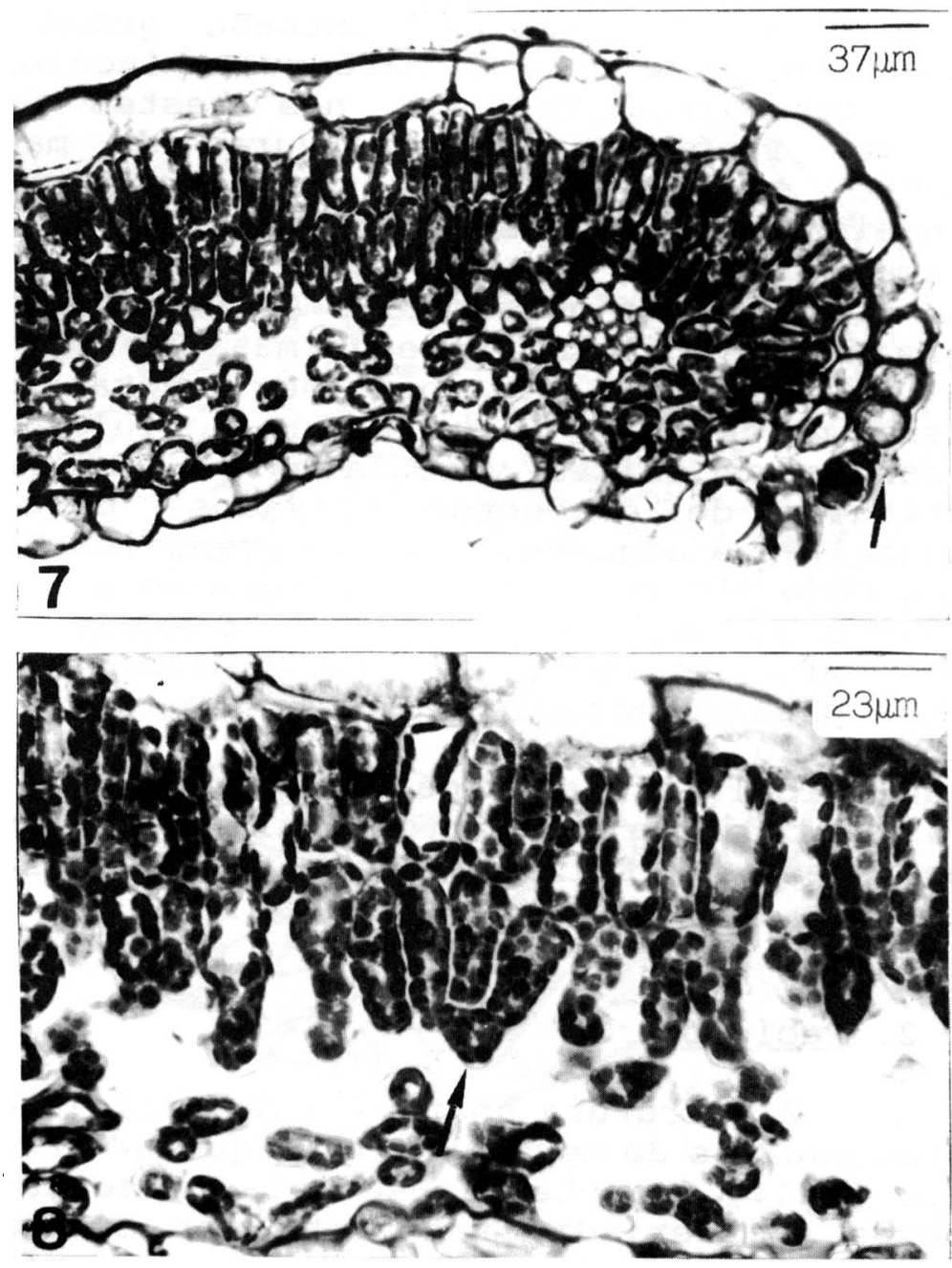

Figura 7 - Corte transversal do bordo foliar. o parênquima paliçádico não se interrompe nesta região. A seta indica a cutícula espessa.

Figura 8 - Corte transversal do mesófilo. A seta indica uma célula coletora ligada a outras três células do parênquima paliçádico. 
duas camadas de células contendo grãos de amido. Algumas células do parênquima íncolor e outras da bainha reagiram nos testes para compostos fenólicos. Nas nervuras de maior diametro, sob as epidermes, pode ocorrer um colênquima. Os feixes vasculares de menor calibre (Figura 6) são do tipo colateral e se acham distribuidos no mesofilo (b); apresentam uma bainha de células parenquimaticas que se pode estender até as epidermes. Nota-se a presença de cristais de oxalato nas células que acompanham os feixes vasculares. o floema é constituído de elementos crivados, células companheiras e algumas células parenquimáticas de conteúdo não identificado. Segue-se a faixa cambial e xilema, composto de elementos traqueais com espessamento do tipo espiralado e de células parenquimáticas, algumas com conteúdo desconhecido, semelhante ao do floema. Na região apical (a), situada num nivel inferior ao do hidatódio, a nervura central é constituída por apenas um feixe colateral, cujas características estão descritas acima.

\subsection{Peciolo}

A estrutura anatômica do pecíolo das plantas adultas do morangueiro "Sequóia" (Figuras 10 e 11), caracteriza-se pela presença de epiderme unisseriada, recoberta por cuticula delgada. Os estômatos encontram-se num nivel inferior ao das demais células epidérmicas; a câmara sub-estomatica apresenta-se pouco desenvolvida. Ocorrem tricomas tectores e glandulares já descritos para a lâmina foliar.

Abaixo da epiderme há cerca de três camadas de colênquima de espessamento do tipo anelar (Figura 11). Segue-se o parênquima fundamental, onde se observam idioblastos contendo drusas de oxalato de calcio (Figura 11). Verificou-se que algumas células da epi- 

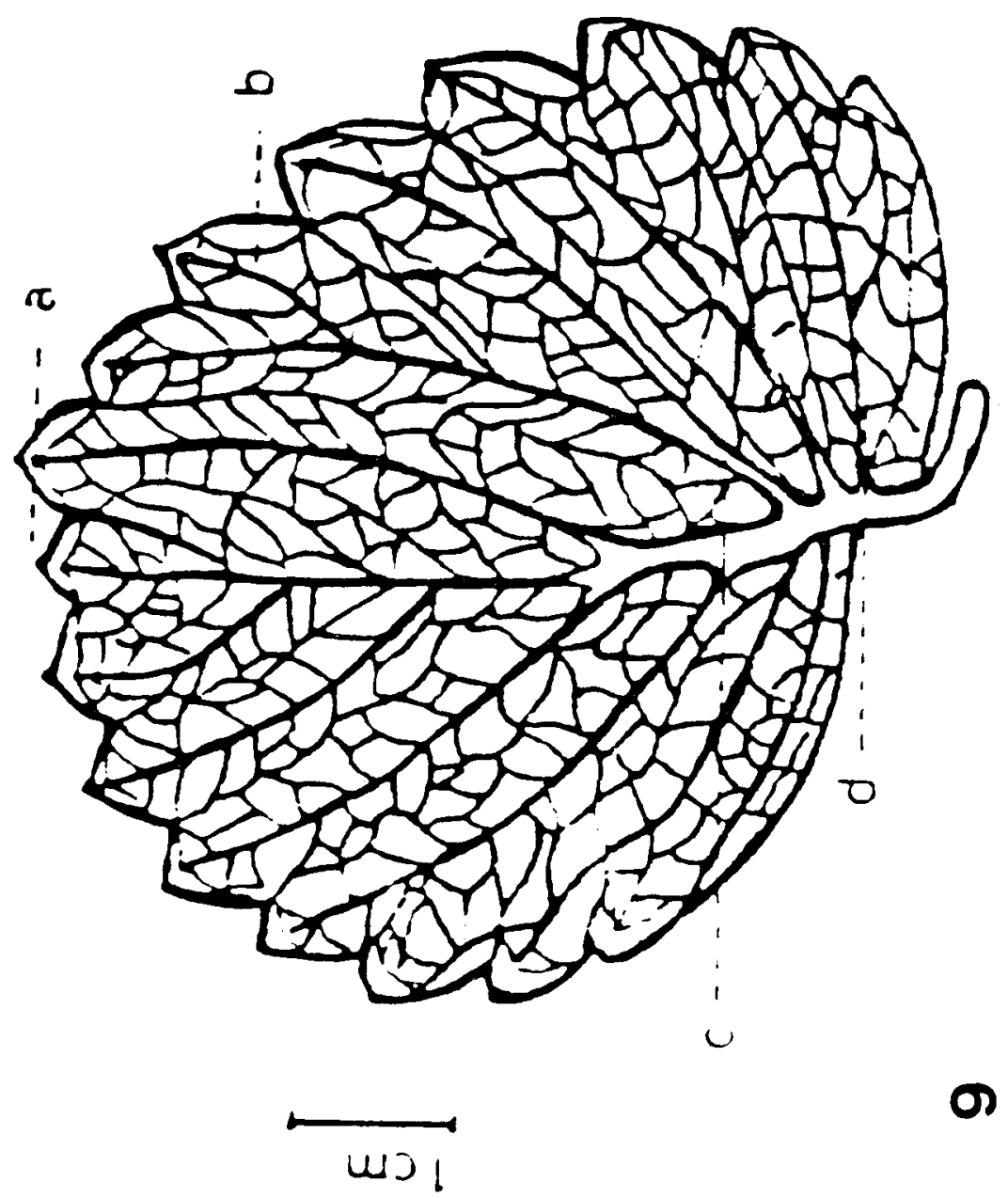

O)

Figura 9 - Padrão de vena foliar; há uma única nervura principal da qual partem as secundarias. 

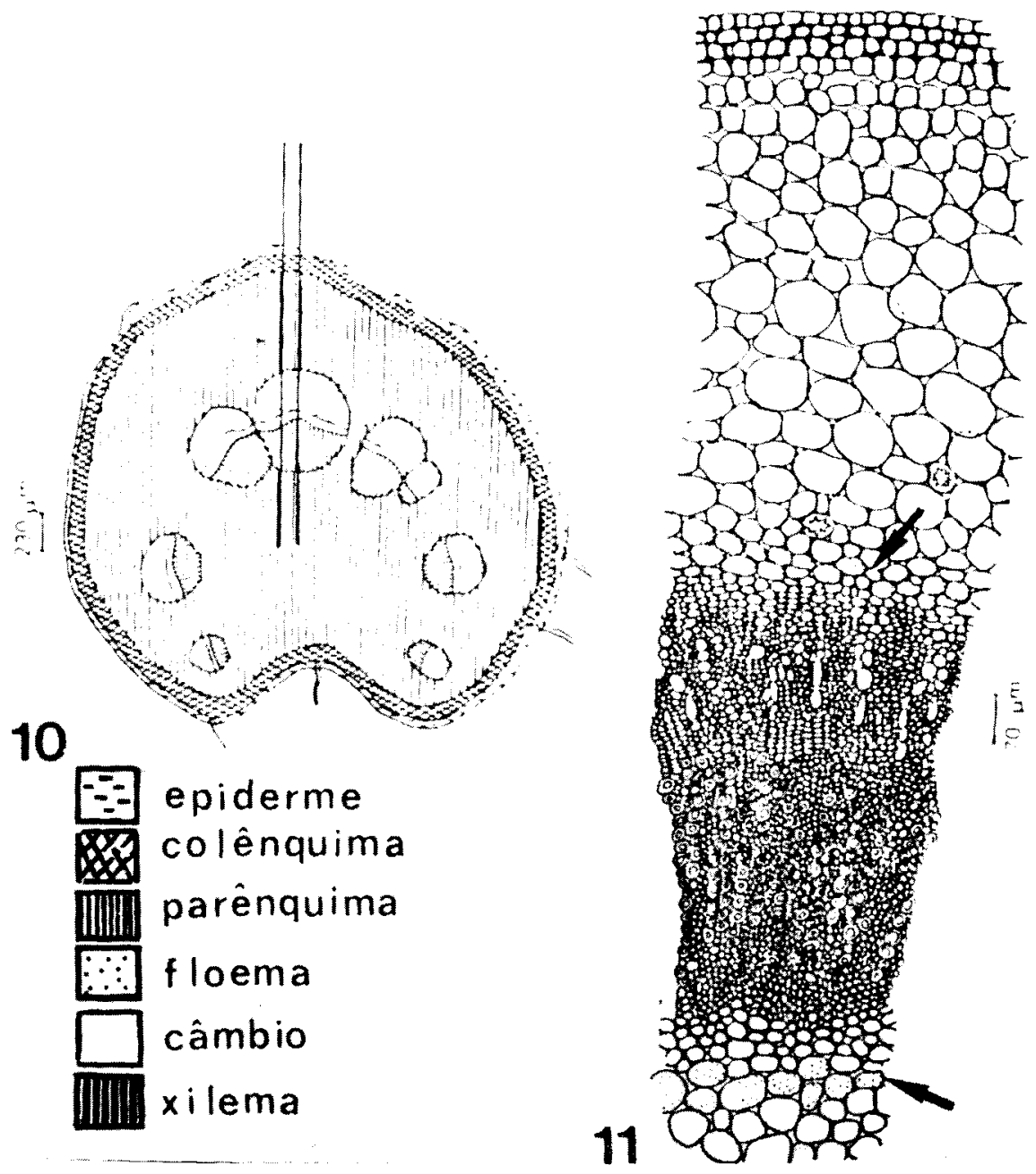

Figuras 10 e 11 - Diagrama do corte transversal do pecíolo. A faixa entre os niveis assinalados está representada na Figura 11. As setas indicam a bainha amilifera. 
derme e do parênquima têm afinidade para compostos fenólicos. O cilindro vascular é descontínuo, formando um arco constituido de feixes do tipo colateral aberto, envolvido por uma bainha composta de duas camadas de células parenquimáticas, contendo grãos de amido (Figura 11, seta). Algumas células da camada mais interna reagiram para compostos fenólicos. No floema, ocorre a lignificação parcial das células do protofloema. Caracteriza-se, ainda, pela presença de algumas células parenquimáticas cujo conteúdo não foi identificado nos testes histoquímicos empregados. Segue-se a faixa cambial e o xilema que é composto por elementos traqueais espiralados, além de células parenquimáticas, cujo conteúdo, é semelhante àquele comentado para o floema.

\subsection{Pedúnculo Floral}

A estrutura anatômica do pedúnculo floral em plantas adultas (Figura 12) difere daquela descrita para o pecíolo por apresentar - parênquima cortical com as duas últimas camadas de células caracterizadas pelo acúmulo de amido; fibras perivasculares formando um anel contínuo com cerca de cinco camadas de células (Figura 13, seta maior); o cilindro vascular quase contínuo interrompido por raios medulares estreitos, cujas células podem sofrer lignificação (Figura 13, seta menor). O floema apresenta elementos crivados conspicuos, células companheiras e algumas células parenquimáticas com conteúdo não identificado pelos testes histoquimicos empregados (Figura 13). Os elementos traqueais do xilema apresentam espessamento espiralado. Na medula foram observados idioblastos contendo drusas. 

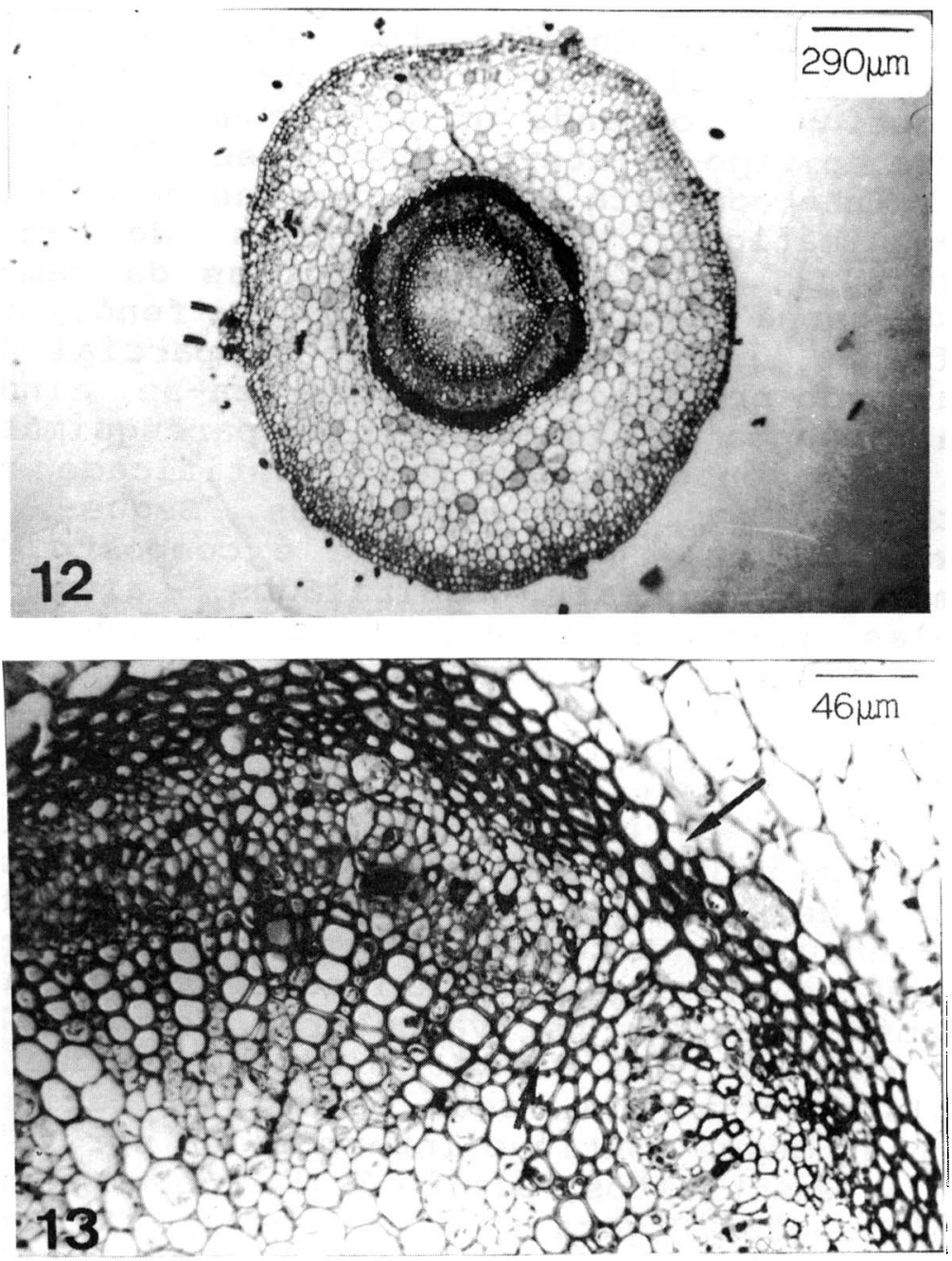

Figura 12 - Corte transversal do pedúnculo floral.

Figura 13 - Detalhe de um feixe vascular. A seta maior indica a presença de $f i-$ bras perivasculares e a seta menor, a lignificação de células do raio medular. 
2. Comparacão das Características Anatômicas das Plantas Tratadas com o controle

Nenhum dos fitorreguladores estudados alteraram a estrutura do morangueiro. 0 GA3 promoveu um alongamento do pedúnculo floral em relação aos demais tratamentos, porém este não resultou em alterações ao nivel anatômico. Nota-se nas Figuras 14 e 15, correspondentes ao corte transversal do pedúnculo que não houve alterações nas células do colênquima entre o controle e o GA3, respectivamente. As Figuras 16 e 17, representam um detalhe da região do cilindro vascular do pedúnculo floral do controle e do GA3, respectivamente. Observa-se que não houve alterações quanto ao número e espessamento das células que compõem $\circ$ anel esclerenquimático, assim como a nível dos elementos traqueais.

\section{DISCUSSÃo}

As características anatômicas estudadas do cultivar "Sequóia" coincidem com os aspectos gerais descritos por METCALFE \& CHALK (1950), para o gênero Fragaria e demais membros da família Rosaceae.

Os tricomas tectores e glandulares observados são comuns na família. No morangueiro os estômatos ocorrem nas duas faces, concentrados na face abaxial, como era esperado pela descrição de METCLAFE \& CHALK (1950), dos aspectos gerais das rosáceas.

A presença das folhas denteadas providas de estruturas secretoras, cuja epiderme não é organizada em paliçada (METCALFE \& CHALK, 1950), foi confirmada para o cultivar estudado. Nos apices dos "dentes" ocorrem hidatódios. A estrutura dos hidatódios encontrados no "Sequóia", é semelhante àquela descrita por DONNELLY \& SKELTON (1987), para morangueiros "Totem". Algumas diferenças encontradas foram 


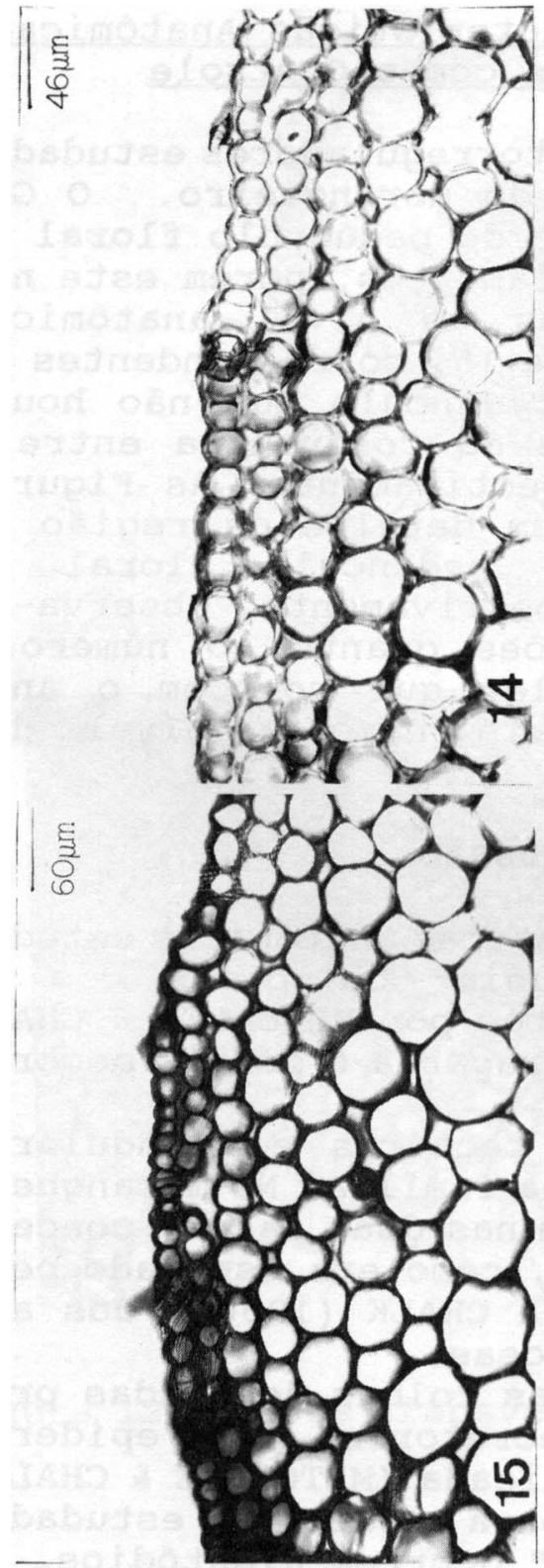

Figuras 14 e 15 -

Detalhe do colênquima do pedúnculo floral, em corte transversal, dos tratamentos controle e $\mathrm{GA}_{3}$, respectivamente.
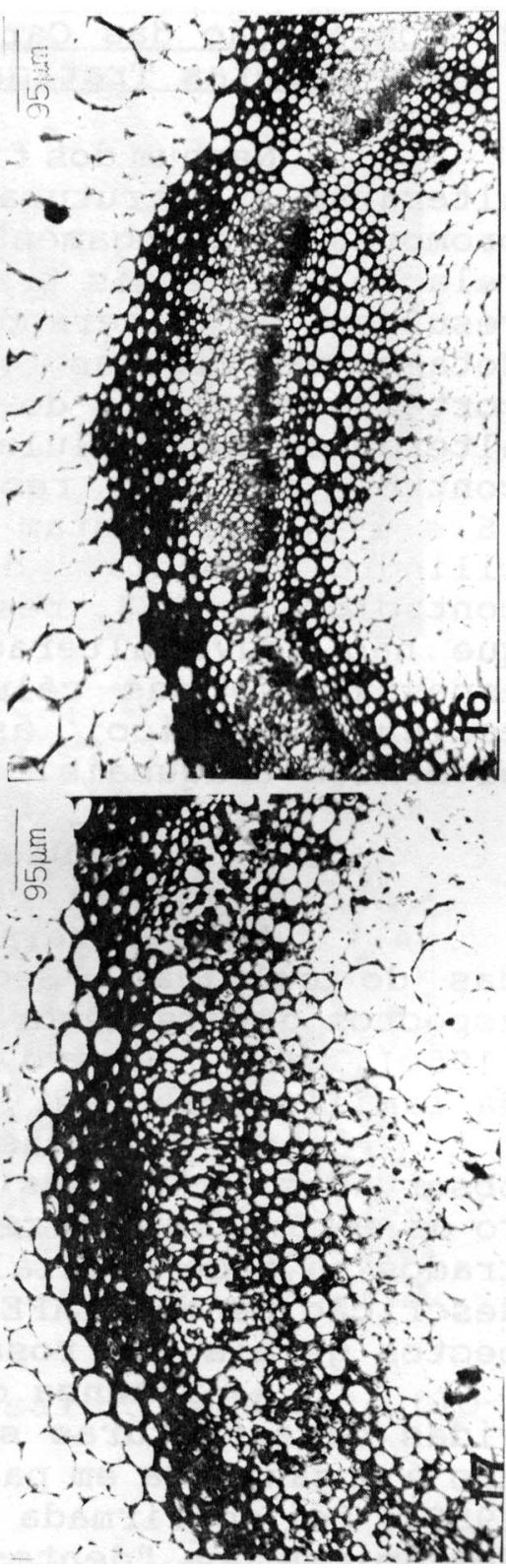

Figuras 16 e 17 -

Corte transversal do cilindro vascular do pedúnculo floral dos tratamentos controle e $\mathrm{Ga}_{3}$, respectivamente. 
a presença de células clorofiladas no epitema e o tamanho das células epidérmicas nesta região. DONNELLY et alii (1987), encontraram tanino nas células da bainha dos feixes que envolvem o tecido do epitema, em hidatódios de folhas de amora. Embora em morangueiro "Sequóia" não tenha sido observada esta característica na região do epitema, comprovou-se que o tanino pode estar presente nas células da bainha dos feixes do limbo e peciolo.

No presente estudo, observou-se uma proeminência na superfície do limbo foliar caracterizada por células suberificadas semelhante à uma lenticela. O problema da denominação de áreas suberificadas, de verruga ou lenticela em lâmina foliar foi discutido por MORRETES \& VENTURELLI (1985). Segundo FONT QUER (1985) verruga é uma proeminência, mais ou menos arredondada, na superfície de um órgão, sendo esse termo usado como sinônimo de lenticela. As lenticelas são definidas por ESAU (1984), como regióes em que o felogênio, por sua atividade, forma um conjunto de células suberificadas ou não, de arranjo frouxo e que ocasionam a protrusão da epiderme, inclusive o seu rompimento, e ocorrem em caules, raízes e frutos. MORRETES \& VENTURELLI (1985) citam que, em 1897, Matteucci chamou a atenção ao fato de ser ou não possivel denominar de lenticelas as áreas suberificadas das folhas. A ocorrência de tais estruturas no limbo e pecílo, foram referidas em 1875, por Poulsen, mencionando sua origem epidérmica ou sub-epidérmica. Quanto à localização da estrutura, alguns autores relacionam-na com os locais de inserção de tricomas, presença de estômatos ou de grupos deles, ou ainda verrugas no lugar de espinhos. A estrutura encontrada na face abaxial do follolo do morangueiro "Sequóia", coincide com algumas características que fazem parte da descrição clássica de lenticelas, relacionadas por MORRETES \& VENTURELLI (1985); não se verificou 
a presença de estômatos na estrutura e nem seu espessamento parietal, embora seja necessário esclarecer que a lenticela nas amostras analisadas de morangueiro tenha sido observada sempre num estágio de desenvolvimento avançado, no qual, inclusive, já ocorreu o rompimento da epiderme.

De acordo com METCALFE \& CHALK (1950), nas rosáceas é comum o parênquima paliçáico constituido de duas ou mais camadas, inclusive em Fragaria. No experimento, o mesofilo do "Sequóia" apresentou até três camadas de paliçádico.

Verificou-se no presente estudo, que as células da bainha dos feixes de menor calibre, imersos no mesofilo, apresentavam um conteúdo que não foi identificado em nenhum dos testes histoquímicos empregados, assemelhandose aos cloroplastos das células do mesofilo adjacente. ESAU (1965) registra a presença de alguns cloroplastos nas células da bainha do feixe em folhas de pêra, outra rosácea.

No peciolo do gênero Fragaria (METCALFE \& CHALK, 1950), os feixes vasculares estão dispostos em forma de arco. No cultivar estudado, o número de feixes que compõem o arco é variável, conforme a região observada.

A presença de colênquima e do anel esclerenquimático em torno do cilindro vascular, referida por METCALFE \& CHALK (1950), como caracteristicas de caules jovens de alguns representantes da familia Rosaceae, foi observada no pedúnculo floral do "Sequóia". Estes autores descrevem que os feixes vasculares em caules são bem distintos uns dos outros, separados por raios parenquimáticos conspicuos. No pedúnculo floral do "Sequóia" esta separação não é nitida, dando a impressão de que o cilindro vascular e contínuo, pois, os feixes são separados por raios medulares estreitos. A medula nas rosáceas pode ser homogênea ou 
heterogênea (SOLEREDER, 1908 ; METCALFE \& CHALK, 1950). No morangueiro "Sequóia" é homogênea. Neste estudo não foram detectados efeitos fitoreguladores sobre a estrutura anatômica de plantas de morangueiro "Sequóia". Efeitos sobre o comprimento das células, o crescimento dos feixes e diferenciação histológica de pecíolos, que são atribuídos às auxinas (AUDUS, 1964) não foram verificados. Wassemberg e Goodrich, citados por AUDUS (1964) constataram reduçāo de cristais de oxalato de cálcio em folhas de Datura stramonium tratadas com 2,4-D, que é uma auxina. Este efeito não foi observado no presente estudo. Segundo BRADLEY et alii (1968), o ácido 2,4,5-triclorofenoxiacético aplicado em folhas adultas de damasco provocou aumento no diâmetro do pecíolo, resultante do aumento do volume das células do tecido de preenchimento e do desenvolvimento do floema e xilema secundários. No morangueiro nenhum destes efeitos foi observado, nem mesmo espessamento do parênquima paliçádico, como foi encontrado em folhas de macieira tratadas com ácido naftalenoacético, mencionado por pickett e Bates, citados por BRADLEY et alii (1968).

No presente estudo, o tratamento com ácido giberélico (30 ppm) não alterou as características anatômicas. Porém, GUTTRIDGE \& THOMPSON (1959), aplicaram o fitohormônio em morangueiros, resultando em aumento do número e do tamanho das células, promovendo o alongamento dos pecíolos. Também PATHAK \& SINGH (1978), que aplicaram uma dose de 75 ppm do mesmo produto em dois cultivares de morango, observaram alterações no comprimento de células da epiderme e parênquima, no tamanho do feixe vascular central e no tamanho e número dos vasos do xilema do mesmo, no pecílo e limbo foliar. É provável que o ácido giberélico não tenha alterado a estrutura anatômica do "Sequóia" em função da dosagem utilizada. 


\section{CONCLUSÕES}

1 - A folha é anfihipoestomática, com estômatos anomociticos.

2 - A lâmina foliar apresenta hidatódios, tricomas tectores e glandulares e estruturas semelhantes à lenticelas.

3 - o mesofilo é dorsiventral, apresentando algumas células coletoras no parênquima lacunoso.

4 - o padrão de venação é do tipo camptodroma arqueado típico.

5 - Os reguladores vegetais, GA3 e NAA, e os bioestimulantes Ergostim e Atonik, aplicados na dose total de $30 \mathrm{ppm}$, não alteraram a estrutura anatômica do limbo foliar, pecíolo e pedúnculo floral comparados à estrutura das plantas controle.

\section{REFERÊNCIAS BIBLIOGRÁFICAS}

AUDUS, I.J., ed. The physiology and biochemistry of herbicides. New York, Academic Press, 1964. 555p.

BRADLEY, M.V.; CRANE, J.C.; MAREI, N. Some histological effects of $2,4,5-$ trichlorophenoxyacetic acid applied to mature apricot leaves. Botanical Gazette, Chicago, 129(3): 231-8, 1968.

CHAMBERLAIN, C.J. Methods in plant histology. 5. ed. Chicago, University of Chicago Press, 1938. 416p. 
CRONQUIST, A. An integrated system of classification of flowering plants. New York, Columbia University Press, 1981. $1243 \mathrm{p}$.

DONNELLY, D.J. \& SKELTON, F.E. Hydathode structure of micro-propagated plantlets and green house-grown "Totem" strawberry plants. Journal of the American Society for Horticultural Science, Geneva, 112(5): 755-9, 1987.

DONNELLY, D.J.; SKELTON, F.E.; NELLES, J.E. Hydathode anatomy and adaxial water loss in micropropagated "Silvan" blackberry. Journal of the American society for Horticultural Science, Geneva, 112(3):566$9,1987$.

DOP, P. \& GAUTIÉ, A. Manuel de tecnique botanique. 2.ed., Paris, Lamarre, 1928 . $594 \mathrm{p}$.

ESAU, K. Plant anatomy. New York, John Wiley \& Sons, 1965. 767p.

ESAU, K. Anatomia das plantas com sementes. São Paulo, Edgard Blucher, 1984. 293p.

FONT QUER, P. Dicionario de Botânica. Barcelona, Labor, 1985. $1244 \mathrm{p}$.

FOSTER, A.S. Practical plant anatomy. New York, Van Nostrand, 1984. 228 p.

GUTTRIDGE, C.G. \& THOMPSON, P.A. Effect of gibberellic acid on lenght and number of epidermal cells in petiole of strawberry. Nature, London, 183(1): 197-8, 1959. 
JOHANSEN, D.A. Plant microtechnique. New York, McGraw-Hill, 1940. 523p.

METCALFE, C.R. \& CHALK, L. Anatomy of the dicotyledons. Oxford, Claredon Press, 1950. v.1-2.

MORRETES, B.L. \& VENTURELLI, M. Ocorrência de "Lenticelas" em folhas de Tripodanthus acutifolius (R.\& P.) Tiegh (Loranthaceae). Revista Brasileira de Botânica, São Paulo, 8: $157-62,1985$.

PATHAK, R.K. \& SINGH, R. Effect of GA and photoperiod on the anatomy of strawberry cultivars. Punjab Horticultural Journal, New Delhi, 18(1/2): 78-86, 1978 .

SASS, J.E. Botanical microtechnique. Iowa, Iowa State College, 1951. 228p.

SOLEREDER, H. Systematic anatomy of the dicotyledons. Transl. by L.A. Boodle and F.E. Fritsch. Oxford, Claredon Press, 1908, v.1-2.

STRASBURGER, E. Handbook of practical botany. 7.ed. Transl. by W. Hillhouse. London, George Allen, 1913. 527p.

WAREING, P.F. \& PHILLIPS, I.D.J. The control of growth and differentiation in plants. Oxford, Pergamon Press, 1970. 303p.

Trabalho entregue para publicação em 23.08 .90 Trabalho aprovado para publicação em 04.07 .91 